\title{
The Original Connection of Synchronous Motor
}

\author{
R. G. Khadeev \\ State Research and Test Institute of Military Medicine, Moscow, Russia \\ Email:khadeev@mail.ru
}

How to cite this paper: Khadeev, R.G. (2017) The Original Connection of Synchronous Motor. Engineering, 9, 680-682. https://doi.org/10.4236/eng.2017.97041

Received: June 30, 2017

Accepted: July 13, 2017

Published: July 27, 2017

Copyright $\odot 2017$ by author and Scientific Research Publishing Inc. This work is licensed under the Creative Commons Attribution International License (CC BY 4.0).

http://creativecommons.org/licenses/by/4.0/

\section{Open Access}

\begin{abstract}
The proposed mechanism was described earlier in the article: Synchronous Motor for the Vehicle, Volume 9, Number 3, March 2017. This article contains some explanations about a synchronous motor with a built-in excitation generator, the stator of which can rotate and is connected through an asymmetric differential.
\end{abstract}

\section{Keywords}

Synchronous Motor, Asymmetric Differential, Gear Ratio, Torque

\section{Introduction}

Is it possible to give to the synchronous motor very valuable, properties previously unattainable, such as a multiple increase in torque at the output shaft? In the article some explanations about a synchronous motor with a built-in excitation generator, the stator of which can rotate and is connected through an asymmetric differential, are included [1]. In this case, the conversion of the revolutions and the torque at the output shaft will occur automatically. These parameters will depend on the required values.

\section{Operation of the Device}

The synchronous motor with a built-in excitation generator, the stator of which can rotate and is connected through an asymmetric differential, is shown in the Figure 1.

By switching on, rotation is transmitted to the output shaft through the elements of planetary differential and partly through the rotation of entire mechanism with the generator around its axis. The rotor of excitation generator 3 is mounted on the shaft 2 and has a dead joint to the motor rotor. The stator of the excitation generator 4 is connected to one of the outlets of planetary differential, to the central wheel 5 and tends to rotate in the direction opposite to the direction 


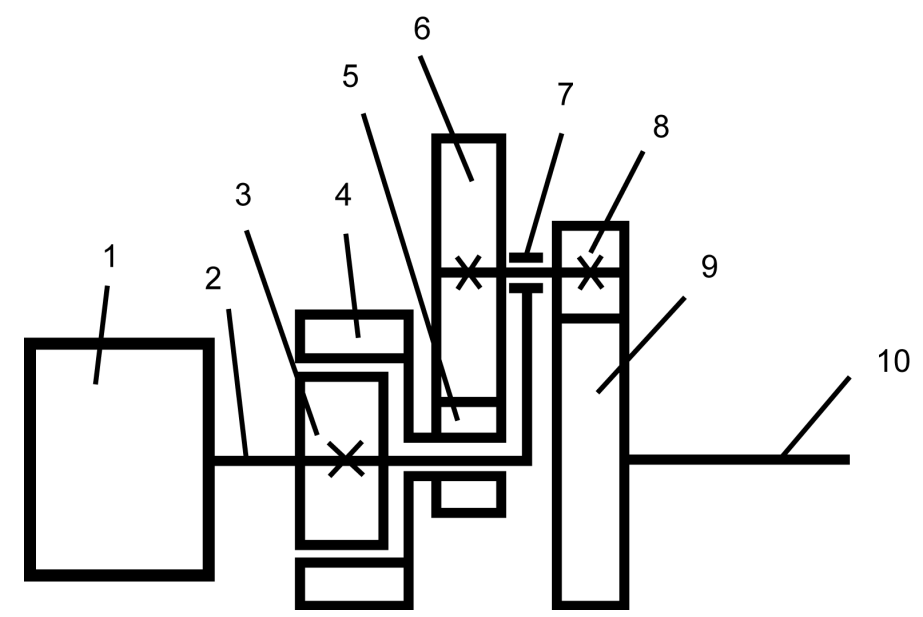

Figure 1. 1. Synchronous electric motor. 2. Shaft of the electric motor. 3. Rotor of the excitation generator. 4. Stator of the excitation generator. 5. Central wheel. 6. Satellite. 7. Carrier of the differential. 8. Satellite. 9. Second central wheel. 10. Output shaft.

of rotation of the motor and output shaft, but it is entrained for the rotor of the generator by the magnetic induction force, when the generator is operating. As the load on the output shaft 10 decreases, the sliding between the rotor and the stator of excitation generator decreases, the entire mechanism rotates around the axis of the motor shaft, the ratio of the motor to the output shaft tends to unity, the rolling of the satellites 6 and 8 along the central wheels 5 and 9 slows down, the mechanism rotates faster around the shaft and the output shaft is accelerated. The torque on the output shaft aims to the torque of motor. By increasing load on the output shaft, it is decelerated. The deceleration is transmitted to the central wheel connected to the stator of the excitation generator, the stator of the generator tends to rotate in reverse direction of the motor shaft rotation, the mutual slip of the stator and the rotor of the excitation generator is increasing. Rotation is mostly transmitted through the elements of the differential, the overall gear ratio of the mechanism increases [2]. The torque on the output shaft also increases in multiples to the gear ratio. If slip increases, the stator of the excitation generator with the central gear can stop and even rotate in the opposite direction relative to the housing. In this case, the torque is the maximum and repeatedly exceeds the torque of the electric motor. The gear ratio of the electric motor to the output shaft is also increased by many times that ensures the maximum possible coordination of the rotation of the electric motor and the wheel. To provide current excitation, it usually takes seven, eight percent of the energy from the network or from the electric motor. These costs are unavoidable in any mode of operation of the electric motor and are not losses. Therefore, for a synchronous motor, it is necessary to set the ratio of the differential one to fifteen to twenty that gives maximum torque increase on the output shaft in fifteen, twenty times. For vehicles, it is enough to increase the torque by six, eight times. Both energy flows are compared in the differential and affect each other. For the nominal load mode, it is necessary, by choosing the differential ratio, to 
balance the electric motor and the excitation generator in order to obtain a slip between its rotor and stator, and hence the excitation current, which ensure the optimum operation of the motor. By increasing load on the output shaft, it is decelerated that leads to an increase of slip between the rotor of the excitation generator and its stator, which is connected to the second output of the differential. The excitation current will increase, which is necessary when the load on the synchronous motor shaft is increased to ensure its economy. In order to ensure automatic regulation of the excitation current, which is necessary by change of the load on the shaft, it is necessary to include in the excitation circuit devices for limiting the excitation generator current if the range of variation of the operating parameters is too wide. It does not prevent from applying of the scheme with such an excitation generator, avoiding using of current collectors, and improves the economic performance of the motor. When starting the motor, it is not necessary to switch the armature of the motor to the starting mode, because when there is no load on the output shaft, the slip between the stator and the rotor of the excitation generator is minimal and does not produce a large current. Connecting the load to the output shaft will lead to the operation of the excitation generator, as there will be a slip between its rotor and the stator.

\section{Conclusions}

So, this simple device solves the following problems:

1) The torque on the output shaft increases as much as possible automatically, as it is done in the automatic gearbox that is not achievable with a different connection of the electric motor.

2) The speed of the shaft of the electric motor and driven wheel coordinated in an automatic mode with the maximum possibility, which ensures the optimality of the transmission in terms of economy.

3) It provides automatic adjustment of excitation of the electric motor, which also improves economic parameters.

\section{References}

[1] Khadeev, R.G. (2017) Synchronous Motor for the Vehicle. Engineering, 9, 251-253. https://doi.org/10.4236/eng.2017.93012

[2] Khadeev, R.G. (2015) A Simple Way to Control the Torque and Turns the Electric Motor. International Journal of Emerging Engineering Research and Technology, E-Poster 3 
Submit or recommend next manuscript to SCIRP and we will provide best service for you:

Accepting pre-submission inquiries through Email, Facebook, LinkedIn, Twitter, etc. A wide selection of journals (inclusive of 9 subjects, more than 200 journals)

Providing 24-hour high-quality service

User-friendly online submission system

Fair and swift peer-review system

Efficient typesetting and proofreading procedure

Display of the result of downloads and visits, as well as the number of cited articles Maximum dissemination of your research work

Submit your manuscript at: http://papersubmission.scirp.org/

Or contact eng@scirp.org 